\title{
Successful island reintroductions of New Zealand robins and saddlebacks with small numbers of founders
}

\author{
Sabrina S. Taylor ${ }^{1, \dagger}$, Ian G. Jamieson ${ }^{1}$ and Doug P. Armstrong ${ }^{2}$ \\ ${ }^{1}$ Department of Zoology, University of Otago, PO Box 56, Dunedin, New Zealand \\ ${ }^{2}$ Wildlife Ecology Group, Massey University, Private Bag 11222, Palmerston North, New Zealand \\ (First received 10 June 2004; resubmitted 20 January 2005; accepted 16 March 2005)
}

\begin{abstract}
Populations established with a small number of founders are thought to have a high risk of extinction due to Allee effects, demographic stochasticity, inbreeding and reduced genetic variation. We tested whether the initial number of birds released was related to persistence in reintroductions of saddlebacks (Philesturnus carunculatus) and robins (Petroica australis) to New Zealand offshore islands. Data were analysed for 31 populations that had been observed for at least 3 years since reintroductions. The numbers released ranged from 5-188. Most of the populations (26) survived and grew, including five from less than 15 founders, and four out of the five extinctions were attributable to introduced mammalian predators. The number of individuals released did not significantly affect extinction probability. The ability of these small releases to establish populations can be attributed to the closed nature of the islands (allowing birds to find mates), low mortality rates following release and high growth rates at low density. Stochastic simulation models based on data from two reintroduced populations suggested that populations with four founders (two male, two female) would have a negligible chance of extinction through demographic stochasticity and would be able to grow even if there were high rates of egg failure through inbreeding.
\end{abstract}

\section{INTRODUCTION}

Comparative analyses of bird and mammal reintroductions has shown that the probability of success is correlated with the number of animals released (Griffith et al., 1989; Wolf et al., 1996; Wolf, Garland \& Griffith, 1998). Griffith et al.'s (1989) model suggested that about 80 animals needed to be released to approach the maximum probability of success. While some minimum number is needed to ensure a high probability of success in any reintroduction, it may not be a general rule that as many as 80 animals is necessary.

Griffith et al.'s (1989) asymptote may overestimate release size because managers are unlikely to translocate large numbers of animals unless they judge the reintroduction to have a high probability of success. More importantly, the number of animals needed will depend on circumstances. Small populations will have a high risk of extinction through demographic stochasticity if they suffer a phase of high post-release mortality, meaning the number of founders is much less than the number released, and if their expected rate of increase is low. Small populations can also be driven to extinction through Allee effects such as post-release dispersal that prevents individuals from finding mates, or increased

\footnotetext{
${ }^{\dagger}$ All correspondence to: S.S.Taylor. Tel: 643 479-5441;

Fax: 643 479-7584; E-mail: sstaylor@wildmail.com
}

susceptibility to predation at low densities (Lande, 1999). Small populations may also be prone to extinction due to inbreeding or loss of genetic diversity (Lande, 1999). The impact of these factors will depend on the characteristics of the species and release sites, hence the number of animals that need to be released may vary greatly.

Bird reintroductions in New Zealand have had a high success rate in comparison to the rest of the world (Armstrong \& McLean, 1995). Most reintroductions have been to offshore islands following forest regeneration or eradication of introduced mammalian predators, two factors that have produced favourable habitat. Favourable habitat coupled with high pairing success due to the closed character of island systems and the sedentary nature of these endemic birds (i.e. flightless/reduced flight and nonmigratory) are expected to produce high initial growth rates.

These factors all suggest that the numbers of animals needed for island reintroductions of New Zealand birds may be somewhat less than the numbers needed for many other species and systems. The small number of birds used to successfully re-introduce populations has also been cited as evidence that New Zealand birds are less vulnerable to inbreeding depression (Craig, 1991, 1994; Craig et al., 2000). We assess whether a small number of birds can establish populations in New Zealand as well as the impact that inbreeding depression may have on population growth rates. We used data for 
two passerines, the saddleback (Maori name $=$ tieke) Philesturnus carunculatus and the New Zealand robin (Maori name = toutouwai) Petroica australis, where good data are available from reintroductions to multiple islands. We first analysed success/failure of reintroductions versus number released. We then used stochastic models developed for individual robin and saddleback populations to predict the relationship between the probability of successful reintroduction, numbers released and egg failure rates.

\section{METHODS}

Saddlebacks $(80 \mathrm{~g})$ and robins $(30 \mathrm{~g})$ are small to medium-sized forest passerines, each with a modal clutch size of two eggs and up to four clutches per season (Heather \& Robertson, 1996; Armstrong et al., 2000; Hooson \& Jamieson, 2003a). They are territorial and sedentary, become sexually mature in their first year and form monogamous pairs. Saddlebacks and robins are relatively weak fliers and migration between current island populations is unlikely. After their release, neither species receives any substantial hands-on management. Saddlebacks are classified as secondary cavity nesters but nest in a variety of protected sites other than tree cavities (Heather \& Robertson, 1996; Armstrong et al., 2002; Hooson \& Jamieson, 2003a). Three islands with saddlebacks (Kapiti, Mokoia and Tiritiri Matangi) had nest boxes erected for use but were not used to the exclusion of natural nesting sites (Lovegrove, 1996a; Armstrong et al., 2002; Stamp, Brunton \& Walter, 2002). Both species show evidence of low genetic variation within and between island populations (Livingston, 1994; Ardern \& Lambert, 1997; Lambert et al., 2005; Tepolt, 2005), suggesting the current populations are inbred.

We obtained data for 36 island reintroductions of robins and saddlebacks where success or failure could be assessed. We excluded one robin and four saddleback reintroductions to islands where stoats (Mustela erminea), feral cats (Felis domesticus), Norway rats (Rattus norvegicus) or ship rats ( $R$. rattus) were present. Research has shown that saddlebacks cannot coexist with these predators (Lovegrove, 1996a,b), hence these failed reintroductions provide no information on the importance of numbers of birds released. Other potential predators such as Polynesian rats or kiore (Rattus exulans), possums (Trichosurus vulpecula), mice (Mus musculus) and weka (Gallirallus australis), a native flightless rail, appear to have much less devastating effects (Lovegrove, 1996a,b; Hooson \& Jamieson, 2003b). We therefore included the possible effect of the presence/absence of the lesser predators on the various islands. These predators were ranked according to the risk they posed: $2=$ possum, kiore; $1=$ mice, weka; $0=$ no predators.

Both saddlebacks and robins are relatively easy to survey because they are noisy, respond readily to playback and are attracted to human observers. If subsequent surveys of islands after release events failed to record any birds, we categorised these populations as extinct.
We also considered a population to be quasi-extinct if the numbers of individuals decreased by more than $50 \%$ 3 or more years after the initial release. We did not consider any populations that had been established for less than 3 years, but did include the number of years after release as an explanatory variable in our analysis. In some cases, the same species was translocated to the same island more than once. If these translocations were within 3 consecutive years, we used the total number of released birds as the initial population. If the translocations were separated by more than 3 years, we used the first translocation only (i.e. each island population only occurred once in the analysis).

The effect that the number of birds released had on extinction probability (success/failure) was tested for saddlebacks using logistic regression with predation risk, years since release and island area included as other explanatory variables. None of the six robin populations went extinct and the lack of variation for this variable meant: (1) we were unable to combine the robin and saddleback data in an overall model with species as an explanatory variable, or (2) run a separate model for the robin data (see Results, below). Data were obtained from published papers, personal communication with New Zealand's Department of Conservation staff and the website of the Oceania Section of the Reintroduction Specialist Group (http://www.massey.ac.nz/ Darmstro/ nz_projects.htm). Means and standard deviations are given throughout and statistical analyses were performed using SPSS 11.5 with significance set at $\alpha=0.05$.

We also assessed extinction probability using stochastic matrix models based on Armstrong \& Ewen's (2002) and Armstrong et al.'s (2002) analysis of the reintroduced robins on Tiritiri Matangi Island and Armstrong et al.'s (2005) analysis of the reintroduced saddleback population on Mokoia Island. Both models included demographic stochasticity in births, deaths and sex ratio of offspring, with births sampled from the Poisson distribution and deaths and sex sampled from the binomial distribution. The models tracked both males and females and assumed strict monogamy (i.e. the number of breeding pairs is the number of males or the number of females, whichever is less). The expected finite rates of increase $(\lambda)$ were initially 1.80 and 2.35 for the robin and saddleback populations, respectively, but declined with density. The log odds of juvenile survival was inversely correlated with the number of pairs in both models and for the saddlebacks, the number of fledglings per female declined both with density and with the quality of territories available. We ran each model 500 times and obtained the $2.5 \%$ and $97.5 \%$ percentile for the number of females present at the start of each year.

We used the simulation models both to predict probability of extinction as a function of initial population size and to model the effects that inbreeding depression might have on reintroduced robin or saddleback populations. We examined the effect of egg failure rates (caused by infertility and embryo deaths) because it is a well-established indicator of inbreeding depression (Spottiswoode \& Moller, 2004). No data were available on 
egg failure rates for populations of different initial sizes, so we simply examined the effect of hypothetical increases in egg failure rate. We assumed that a reduction in the proportion of eggs hatching would cause a proportional reduction in the number of young fledged.

\section{RESULTS}

\section{Effects of initial release numbers on extinction probability}

The average number of robins and saddlebacks released during each translocation was $31.3 \pm 26.5$ (range $=$ $5-66, n=6)$ and $34.0 \pm 34.3$ (range $=6-188, n=25$ ) respectively. Little Barrier Island was an outlier with respect to the number of birds released (188) and island area (3083 ha). However, its inclusion in the analysis did not affect the results.

Only five out of 24 island populations of saddlebacks went extinct or quasi-extinct, while none of the six robin populations failed (Table 1). Furthermore, four out of the five failed saddleback populations were on islands with a high risk of predation (Table 1). Two robin releases involved five birds each (in one case, only one pair was reported to have bred successfully: Flack, 1977) and produced populations of 60 birds on 15 ha Allports Island and over 400 on 59 ha Motuara Island (Byrne, 1999).

In the full logistic regression model for saddlebacks, years since release and predation risk were correlated (correlation matrix $r=0.825$ ), preventing model conver-
Table 1. The effects of differential predation risk on establishment success of translocated island populations of saddlebacks and New Zealand robins

\begin{tabular}{cllll}
\hline & & \multicolumn{2}{c}{ Predation risk $^{\dagger}$} \\
\cline { 3 - 4 } Species & Outcome & $\begin{array}{l}\text { Release no. } \\
(\text { mean } \pm \text { SD })\end{array}$ & $0-1$ & 2 \\
\hline Saddleback $(n=25):$ & & 1 & 4 \\
Failed & $21.0 \pm 15.1$ & 17 & 3 \\
Succeeded & $37.2 \pm 37.2$ & & \\
Robin $(n=6):$ & & 0 & 0 \\
Failed & - & 6 & 0 \\
Succeeded & $31.3 \pm 26.5$ & & \\
\hline
\end{tabular}

${ }^{\dagger}$ Predators were ranked according to the risk they posed $(0=$ no predators, $1=$ mice, weka, $2=$ possum, kiore), with categories 0 and 1 combined because of small sample sizes.

gence. When these variables were considered singly, predation risk was significant (Wald $=4.920$, d.f. $=1$, $P=0.027$ ) but years since release was not (Wald $=2.971$, d.f. $=1, P=0.085$ ) so we removed years since release from the model. In the final model, none of the variables were significant, i.e. island area (Wald $=0.016$, d.f. $=1$, $P=0.39$, odds ratio $95 \%$ confidence intervals $(\mathrm{CI})=$ 0.955-1.018; Fig. 1(a)), predation risk (Wald $=2.610$, d.f. $=1, P=0.066$, odds ratio $\mathrm{CI}=0-1.363$ : Table 1$)$, or the number of birds released (Wald $=0.074$, d.f. $=1$, $P=0.3032$, odds ratio $\mathrm{CI}=0.801-1.071$; Fig. $1(\mathrm{~b}))$. The
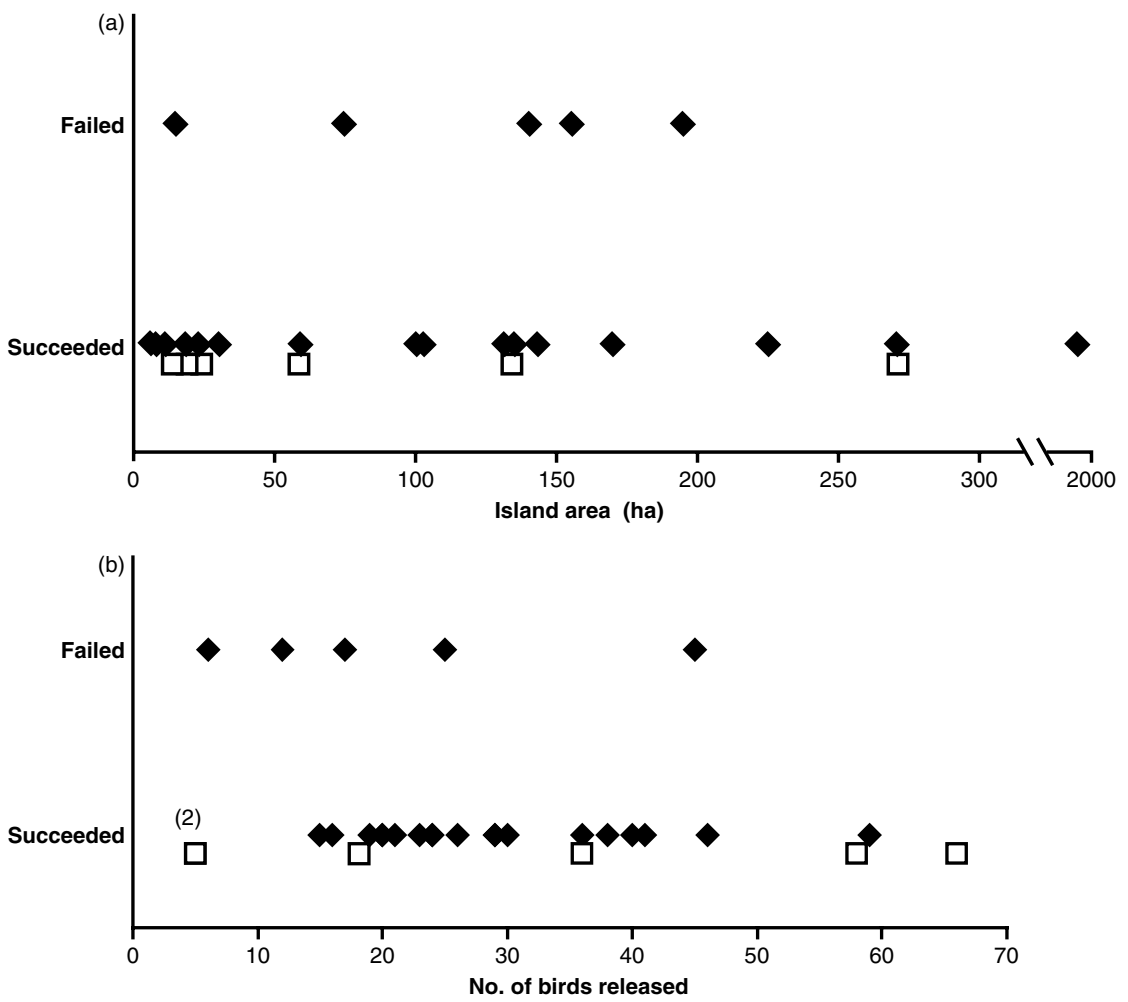

Fig. 1. Number of failed and successful saddleback $(\diamond)$ and robin $(\square)$ populations in relation to: (a) island area and (b) the number of birds released. The successful release and establishment of 188 saddlebacks on Little Barrier Island (3083 ha) is not shown. 
estimated coefficient for the number of birds released was -0.077 , which corresponds to an increase in the probability of extinction from 0.0008 to 0.003 when the number of birds released decreases by $50 \%$ from 34 (the mean number of saddlebacks released) to 17 , assuming a mean island area of 294 ha and low predation risk.

The stochastic simulation models also supported the conclusion that few founders were needed to ensure a high probability of reintroduction success for saddlebacks and robins. Under the parameters estimated for the Mokoia saddleback population and the Tiritiri Matangi robin population, a founder size of only two males and two females was predicted to have $0 \%$ and $2 \%$ chance of extinction in 15 years for observed egg failure rates of $22 \%$ and $15 \%$ respectively (Figs $2(a)$ and $3(a)$ ).

\section{Modelling the effects of inbreeding depression on extinction probability of saddlebacks and robins}

The simulation models also suggest that such populations could experience high levels of egg failure and still grow. Doubling or tripling the egg failure rate of the Mokoia saddleback population slowed growth rates of simulated populations, but produced negligible extinction risk (Figs 2(b) \& (c)). Doubling and tripling the egg failure rate of the Tiritiri Matangi robin population had a more pronounced effect than in the saddlebacks, reflecting the lower finite rate of increase for the robin population, but the simulated populations still had a $67 \%$ chance of persisting with the egg failure rate tripled (Figs 3(b) \& (c)).

\section{DISCUSSION}

The above results are necessarily limited to the period of time over which the island populations have been monitored. Transfer failures were known to have occurred within 3 years of birds being released and so 3 years was set as the lower limit for our analysis. Almost half of the populations have persisted for more than 20 years, or at least an estimated 6-7 generations, which we believe should be long enough to have detected declines in populations if they were occurring. Given our conservative definition of a failed population - the initial release population declined by $50 \%$ or more there appeared to be relatively few failures. Introduced predators such as stoats, cats and rats are still the primary drivers of extinction in saddlebacks and robins, as they are for most of New Zealand's endemic bird fauna (Clout, 2001; Duncan \& Blackburn, 2004). However, when the adverse effects of these major predators are removed, far more translocated populations established successfully than failed and were successful across a wide range of initial populations sizes. This suggests that surviving New Zealand bird populations on small islands are not exceptions to many unobserved or unrecorded extinct populations, as suggested by some authors (Frankham, Ballou \& Briscoe, 2002). Furthermore, relatively small numbers of released birds do not appear to prevent population growth recovery to carrying capacity as long
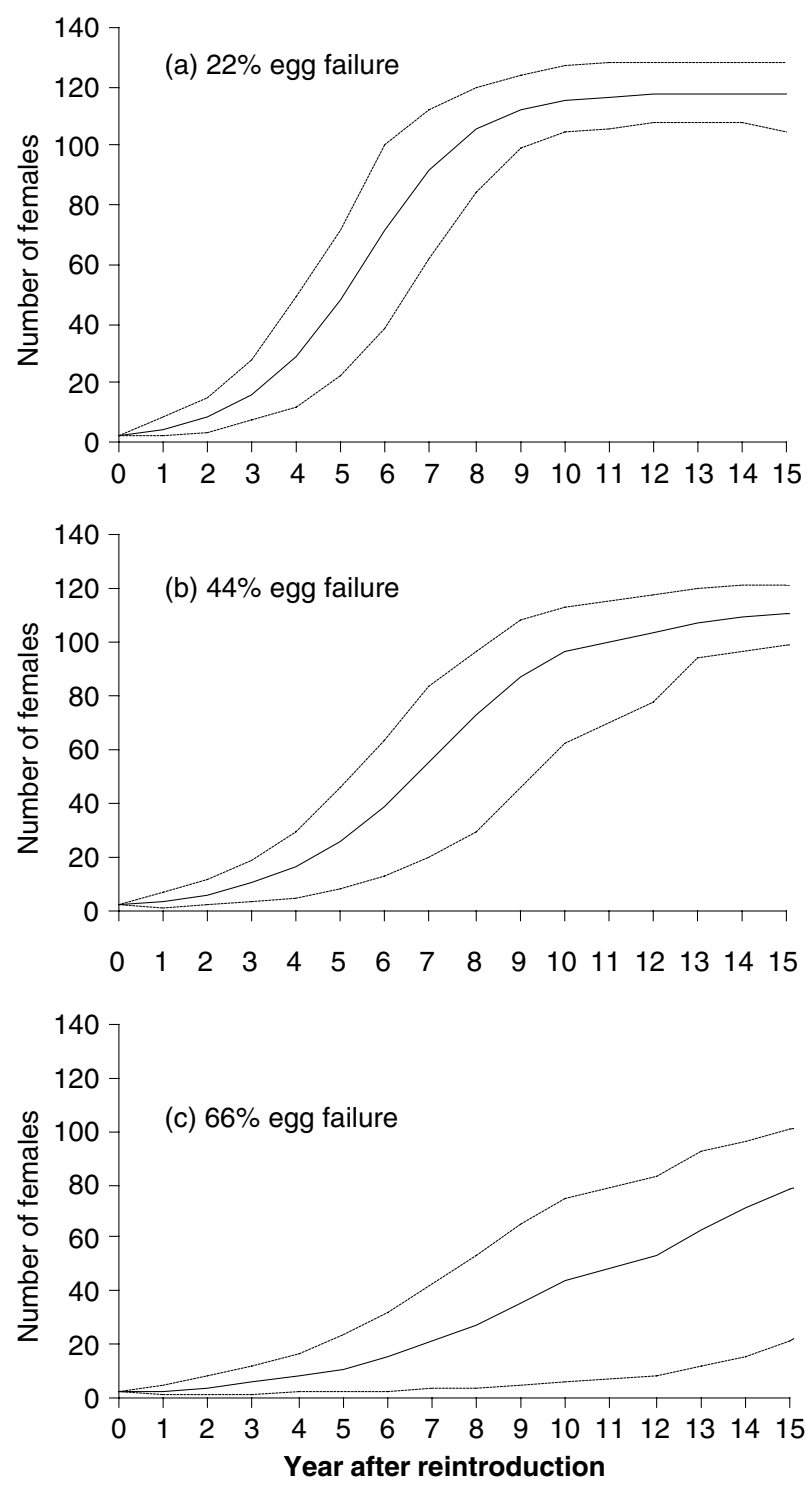

Fig. 2. Growth of simulated saddleback populations on Mokoia Island (135 ha), assuming an initial population of two males and two females. The trajectories show the mean (continuous line), 97.5 percentile (upper broken line) and 2.5 percentile (lower broken line) from 500 simulations incorporating demographic stochasticity in survival, reproduction and sex of offspring. Parameters were estimated from 6 years of data collected on Mokoia and they incorporate density dependence in reproduction and juvenile survival (Armstrong et al., 2005). (a) Incorporates the observed egg failure rate (22\%), while (b) and (c) show the projected effects of hypothetical increases in that rate.

as major introduced mammalian predators are absent or are controlled.

Although small island populations of New Zealand native birds appear to persist, they may still suffer from the detrimental consequences of inbreeding. There is increasing evidence that New Zealand's native birds show a reduction in fitness associated with close inbreeding (Jamieson, Roy \& Lettink, 2003) or severe bottlenecks (Jamieson \& Ryan, 2000; Briskie \& Macintosh, 2004). In addition, Briskie \& Macintosh (2004) have found that hatching failure rates of native birds that have gone 

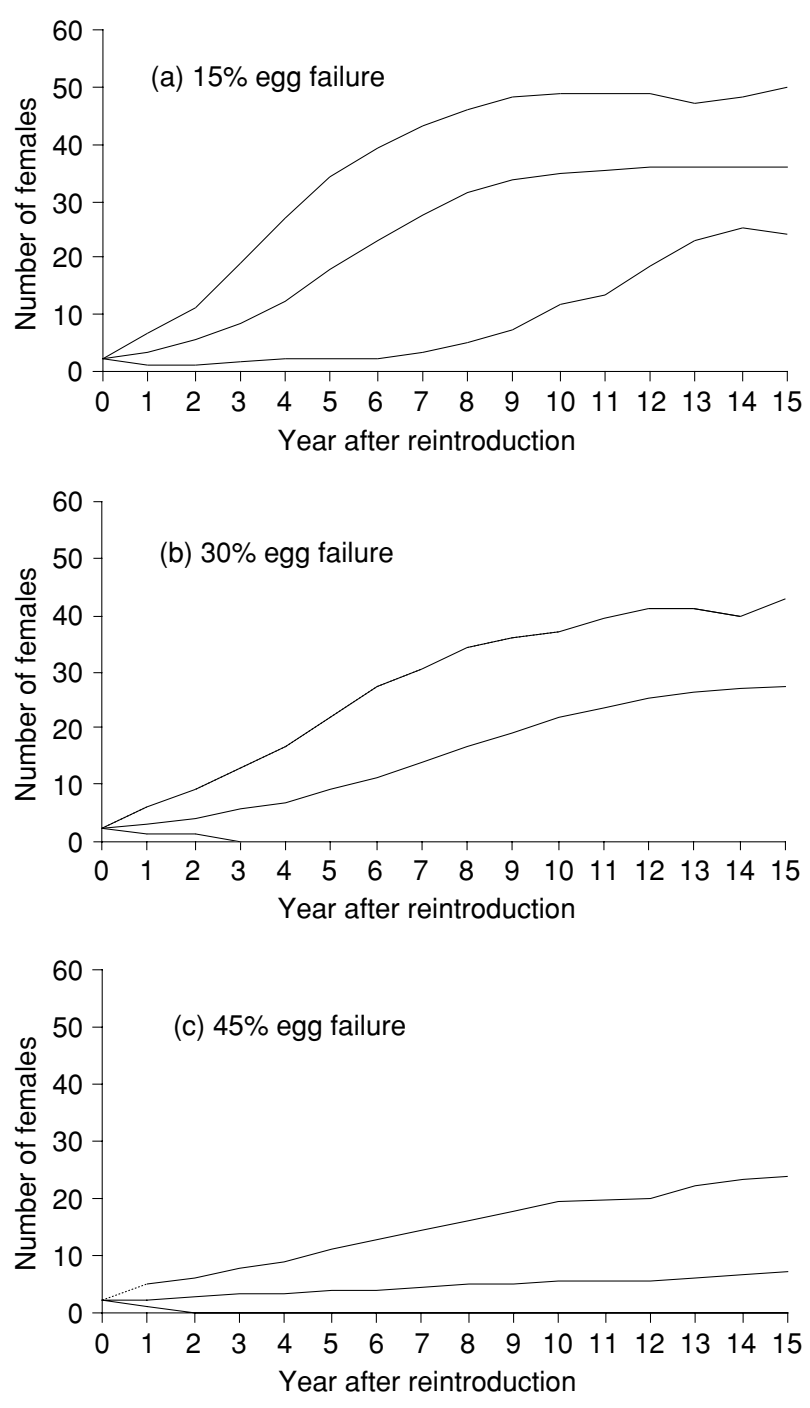

Fig. 3. Growth of simulated New Zealand robin populations on Tiritiri Matangi Island (15 ha of robin habitat), assuming an initial population of two males and two females. Parameters were estimated from 6 years of data collected on Tiritiri Matangi and incorporate density dependence in juvenile survival (Armstrong \& Ewen, 2002). (a) Incorporates the observed egg failure rate (15\%), while (b) and (c) show the projected effects of hypothetical increases in that rate. Other conventions as for Fig. 2.

through bottlenecks of less than 150 individuals are high and not significantly different from introduced birds that have gone through similar sized bottlenecks.

By modelling the release of small numbers of saddlebacks on predator-free islands, we can reconcile these two points of view; the apparent persistence of many small populations and the likelihood that inbreeding depression is occurring. Saddleback and robin populations can still grow even when inbreeding depression in the form of egg failure rates is severe. This is partly the consequence of relatively high survival and reproduction rates associated with low population densities in newly established populations (Armstrong et al., 2002, 2005). Therefore any negative effects of inbreeding depression on fitness traits such as egg fertility and hatchability can still be overcome through rapid population growth, although the greater the inbreeding depression the longer it takes to reach carrying capacity and the slower the recovery from any subsequent population catastrophes. For example, any loss of fitness due to inbreeding in populations that are also subjected regularly to predation events, such as occurs on the mainland of New Zealand, could be the "nail in the coffin' for many threatened species.

\section{CONCLUSIONS}

The results of this study appear to support the perception that translocations of New Zealand native birds to predator-free islands are frequently successful even when relatively few individuals are transferred and released. We have shown that reintroduced saddleback and robin populations can grow in spite of potential inbreeding problems such as high rates of egg failure. Nevertheless, these populations could have lost significant genetic variation through founder events, drift or inbreeding, or a combination of these factors, placing the new populations at greater risk to invading pathogens or environmental perturbations over the long term. The issue of long-term viability of translocated populations established with a small number of founders clearly requires further research.

\section{Acknowledgements}

We thank M. Willans, K. Owen, G. Tomlinson, L. Adams, G. Elliott and G. Moorcroft for supplying unpublished data and B. Niven for statistical advice. Our research on New Zealand robins and saddlebacks was funded by the Department of Conservation, University of Otago (SST, IGJ), the New Zealand Lottery Board, Massey University and Supporters of Tiritiri Matangi Inc. (DPA). S. Taylor received a postgraduate scholarship from the Natural Sciences and Engineering Research Council of Canada.

\section{REFERENCES}

Ardern, S. L. \& Lambert, D. M. (1997). Is the black robin in genetic peril? Mol. Ecol. 6: 21-28.

Armstrong, D. P. \& Ewen, J. G. (2002). Dynamics and viability of a New Zealand robin population reintroduced to regenerating fragmented habitat. Conserv. Biol. 16: 1074-1085.

Armstrong, D. P. \& McLean, I. G. (1995). New Zealand translocations: theory and practise. Pac. Conserv. Biol. 2: 39-54.

Armstrong, D. P., Ewen, J. G., Dimond, W. J., Lovegrove, T. G., Bergstrom, A. \& Walter, B. (2000). Breeding biology of North Island robins (Petroica australis longipes) on Tiritiri Matangi Island, Hauraki Gulf, New Zealand. Notornis 47: 106-118.

Armstrong, D. P., Davidson, R. S., Dimond, W. D., Perrott, J. K., Castro, I., Ewen, J. G., Griffiths, R. \& Taylor, J. (2002). Population dynamics of reintroduced forest birds on New Zealand islands. J. Biogeog. 29: 609-621.

Armstrong, D. P., Davidson, R. S., Perrott, J. K., Roygard, J. \& Buchanan, L. (2005). Density-dependent population growth in a reintroduced population of North Island saddlebacks. J. Anim. Ecol.74: 160 170.

Briskie, J. V. \& Mackintosh, M. (2004). Hatching failure increases with severity of population bottlenecks in birds. Proc. Natl. Acad. Sci., USA 101: 558-561. 
Byrne, A. J. (1999). Effects of population bottlenecks on the South Island robin, Petroica australis australis. MSc thesis: University of Canterbury, Christchurch.

Clout, M. (2001). Where protection is not enough: active conservation in New Zealand. Trends Ecol. Evol. 16: 415-416.

Craig, J. L. (1991). Are small populations viable? Acta XX Congressus Internationalis Ornithologica 2546-2551.

Craig, J. L. (1994). Meta-populations: is management as flexible as nature. In Creative conservation: interactive management of wild and captive animals: 50-66. Olney, P. J. S., Mace, G. M. \& Feistner, A. T. C. (Eds). London: Chapman \& Hall.

Craig, J. L., Anderson, S., Clout, M., Creese, B., Mitchell, N., Ogden, J., Robert, M. \& Ussher, G. (2000). Conservation issues in New Zealand. Annu. Rev. Ecol. Syst. 31: 61-78.

Duncan, R. P. \& Blackburn, T. M. (2004). Extinction and endemism in the New Zealand avifauna. Global Ecol. Biogeogr. 13: 509-517.

Flack, J. A. D. (1977). Interisland transfers of New Zealand black robins. In Endangered birds: management techniques for preserving threatened species: 365-372. Temple, S. A. (Ed.). Madison: University of Wisconsin Press.

Frankham, R., Ballou, J. D. \& Briscoe, D. A. (2002). Introduction to conservation genetics. Cambridge: Cambridge University Press.

Griffith, B., Scott, J. M., Carpenter, J. W. \& Reed, C. (1989). Translocation as a species conservation tool: status and strategy. Science 245: 477-480.

Heather, B. \& Robertson, H. (1996). The field guide to the birds of New Zealand. Auckland: Penguin Books (NZ).

Hooson, S. \& Jamieson, I. G. $(2003 a)$. Breeding biology of the South Island saddleback (Philesturnus carunculatus carunculatus). Notornis 50: 191-199.

Hooson, S. \& Jamieson, I. G. (2003b). The distribution and current status of New Zealand saddleback Philesturnus carunculatus. Bird Conserv. Intl. 13: 79-95.

Jamieson, I. G. \& Ryan, C. J. (2000). Increased egg infertility associated with translocating inbred takahe (Porphyrio hochstetteri) to island refuges in New Zealand. Biol. Conserv. 94: 107-114.
Jamieson, I. G., Roy, M. S. \& Lettink, M. (2003). Sex-specific consequences of recent inbreeding in an ancestrally inbred population of New Zealand takahe. Conserv. Biol. 17: 708-716.

Lambert, D. M., King, T., Shepherd, L. D., Livingston, A., Anderson, S. \& Craig, J. L. (2005). Serial population bottlenecks and genetic variation: translocated populations of the New Zealand saddleback (Philesturnus carunculatus rufusater). Conserv. Genet. 6: 114.

Lande, R. (1999). Extinction risks from anthropogenic, ecological, and genetic factors. In Genetics and the extinction of species: 122. Landweber, L. F. \& Dobson, A. P. (Eds). Princeton: Princeton University Press.

Livingston, A. (1994). Conservation genetics of the saddleback. MSc thesis: University of Auckland, Auckland.

Lovegrove, T. G. (1996a). Island releases of saddlebacks Philesturnus carunculatus in New Zealand. Biol. Conserv. 77: 151-157.

Lovegrove, T. G. (1996b). A comparison of the effects of predation by Norway (Rattus norvegicus) and Polynesion rats (R. exulans) on saddleback (Philesturnus carunculatus). Notornis 43: 91-112.

Mills, L. S. \& Smouse, P. E. (1994). Demographic consequences of inbreeding in remnant populations. Am. Nat. 144: 412-431.

Spottiswoode, C. \& Moller, A. P. (2004). Genetic similarity and hatching success in birds. Proc. R. Soc. Lond. ser. B. 271: 267-272.

Stamp, R. K., Brunton, D. H. \& Walter, B. (2002). Artificial nest box use by the North Island saddleback: effects of nest box design and mite infestations on nest site selection and reproductive success. $N$. Z. J. Zool. 29: 285-292.

Tepolt, C. (2005). Population genetics and retrospective pedigree determination in South Island saddlebacks and New Zealand robins. MSc thesis: University of Otago, Dunedin.

Wolf, C. M., Griffith, B., Reed, C. \& Temple, S. A. (1996). Avian and mammalian translocations: update and reanalysis of 1987 survey data. Conserv. Biol. 10: 1142-1154.

Wolf, C. M., Garland Jr., T. \& Griffith, B. (1998). Predictors of avian and mammalian translocation success: reanalysis with phylogenetically independent contrasts. Biol. Conserv. 86: 243-255. 